\title{
Resting Tremor after Mild Head Injury: Case Report
}

\section{Tremor de repouso após traumatismo cranioencefálico leve: relato de caso}

\author{
Marcelo José da Silva de Magalhães 1,2,3,4 Ana Paula Alkmim Figueiredo Martins ${ }^{2}$ \\ Anna Freitas Cardoso Freire ${ }^{2}$ Jamile Pereira Dias ${ }^{2}$ Ludmila Godinho Ribeiro ${ }^{2}$ Mariana Alves de Oliveira ${ }^{2}$ \\ MateusOliveira Mendes ${ }^{2}$ Monique Rocha de Carvalho ${ }^{2}$ Theresa Cristina Abreu Versiani ${ }^{2}$ \\ ${ }^{1}$ Department of Medicine, Faculdades Integradas Pitágoras de \\ Montes Claros, Montes Claros, MG, Brazil \\ 2 Department of Medicine, Faculdades Unidas do Norte de Minas, \\ Montes Claros, MG, Brazil \\ ${ }^{3}$ Department of Neurosurgery, Hospital Aroldo Tourinho, Montes \\ Claros, MG, Brazil \\ ${ }^{4}$ Department of Neurosurgery, Hospital Vila da Serra-Nova, Lima, MG, Brazil

\begin{abstract}
Address for correspondence Marcelo José da Silva de Magalhães, MD, MSc, Rua Francisco Versiane Athaide, 760, Cândida Câmara, Montes Claros, MG, Brazil. CEP: 39401-039 (e-mail: marcelo7779@yahoo.com.br).
\end{abstract}

Arq Bras Neurocir 2019;38:68-72.

\begin{abstract}
Keywords

- traumatic brain injury

- movement disorder

- posttraumatic

- tremor

Resumo

Palavras-Chave

- traumatismo cranioencefálico

- desordem de movimento

- pós-traumático

- tremor

Over the past few decades, it has been recognized that traumatic brain injury (TBI) may result in various movement disorders. However, moderate or mild TBI only rarely causes persistent post-traumatic movement disorders. In the present report, we describe a case of secondary tremor due to a mild head injury with a transitory loss of consciousness. A 26year-old man developed an isolated rest tremor of the hands and legs without other neurologic signs. The interval between the head trauma and the onset of the symptoms was 4 months. Neuroimaging studies reveled gliosis in the lentiform nucleus. Haloperidol administration resulted in tremor reduction. A rest tremor, similar to essential tremor, can be a rare complication of head trauma. Haloperidol may be an effective and safe treatment modality for post-traumatic tremor. Further studies are needed to clarify the optimal drug for the treatment of post-traumatic tremor.

Nas últimas décadas, tem-se reconhecido que o traumatismo cranioencefálico (TCE) pode resultar em diferentes desordens de movimento. No entanto, somente em raros casos o TCE leve e moderado pode desencadear desordens de movimento. O presente relato apresenta um caso de tremor secundário a um TCE leve, com perda transitória da consciência, cujo paciente, com 26 anos de idade, do sexo masculino, desenvolveu um quadro neurológico de tremor de repouso das mãos e pernas de forma isolada, sem outros sinais neurológicos associados. Note-se que o intervalo entre o TCE e o início dos sintomas foi de 4 meses. $O$ estudo de neuroimagem revelou gliose bilateral no núcleo lentiforme. A administração de haloperidol resultou em controle dos sintomas. Tremor de repouso similar ao tremor essencial é uma rara complicação do TCE. Dentre as modalidades de tratamento efetivas e seguras para o tremor pós-TCE, encontra-se o haloperidol. Entretanto, mais estudos são necessários para definir o medicamento que se mostra mais adequado para o tratamento do tremor pós-TCE.
\end{abstract}

received

July 31, 2015

accepted

October 13, 2016
DOI https://doi.org/

10.1055/s-0036-1595818. ISSN 0103-5355.
Copyright $\odot 2019$ by Thieme Revinter Publicações Ltda, Rio de Janeiro, Brazil
License terms

c) $(1) \$$ 


\section{Introduction}

Traumatic brain injury (TBI) is a cerebral insult caused by an external physical force promoting an anatomical lesion and/or functional compromise of the scalp, of the cranium, of the meninges, or of the brain. ${ }^{1,2}$ Traumatic brain injury is one of the major global public health problems, with a high and increasing incidence in the modern world. ${ }^{1,2}$ It also represents an important cause of morbimortality in adolescents and young adults, leading to a decrease in the productive capacity and in societal financial losses. ${ }^{1,2}$ Regardless of the socioeconomical status, the number of deaths resulting from TBI is surpassed only by neoplastic and cardiovascular diseases. ${ }^{2}$

The incidence of TBI in the United States was estimated in 538.2 cases per 100,000 people; in Europe, in 235 cases per 100,000; and in Australia, in 322 cases per 100,000. ${ }^{3}$ In Brazil, annually, around half a million people are hospitalized due to TBIs. $^{2}$ In the past 10 years, more than 1 million people became disabled due to traffic accidents. ${ }^{1}$

The mechanism of TBI can be divided in: (1) focal brain lesion, resulting in contusion, laceration, and intracranial hemorrhage due to direct local trauma; and (2) diffuse brain lesion, which causes diffuse axonal lesion and brain swelling (edema) by the mechanism of acceleration-deacceleration. ${ }^{4}$ The outcome of the brain lesion is defined by two different mechanisms: (1) primary lesion, which occurs at the moment of the trauma; and (2) secondary lesion, resulting from late clinical manifestations of the pathological process started by the trauma. ${ }^{4}$

The disabilities resulting from TBI can be divided into three categories: physical (sensory-motor), cognitive, and emotional/behavioral. ${ }^{5}$ Physical disabilities are diversified and may include motor, visual, and tactile disabilities. Cognitive disabilities often include attention, memory, and executive function disorders. ${ }^{5,6}$

Post-TBI extrapyramidal alterations are rare, and their manifestation can overlap with Parkinsonism (tremor, dyskinesia and rigidity), which are considered hypokinetic alterations, or with hyperkinetic alterations (chorea, ballismus, and athetosis). ${ }^{7-9}$

The present report describes the case of a patient with post-TBI rest tremor, a rare sequela in this scenario.

\section{Case Report}

Patient W. A. C., male, 26 years old, civil construction worker, married with no children. While riding a bicycle, the patient collided with a motorcycle. The patient lost consciousness at the site of the accident and was transferred to a reference hospital by the mobile emergency service. After the initial treatment, the following tests were performed and did not reveal any abnormalities: computed tomography (CT) of the head, cervical and lumbar spine X-rays, and chest X-ray. Since the patient scored 14 points in the Glasgow coma scale at admission, he remained at the hospital for a 24-hour period.

Four months later, the patient presented to the medical office complaining of rest tremors in the limbs and gait alteration, requiring time off work. In order to perform a more thorough investigation, a magnetic resonance imaging (MRI) exam of the head was performed and revealed small foci of gliosis at the left putamen and at the globus pallidus bilaterally (-Fig. 1). The patient did not report any neurological conditions in his previous or familial history. At the neurological exam, he did not present cranial nerves or muscle strength abnormalities, neither dysmetria nor nystagmus. A frequency rest tremor, more evident in the inferior limbs, mainly on the left side, and of mild intensity in the superior limbs, was observed. Gait was impaired by the tremors in the inferior limbs. Data collected at anamnesis, at the physical exam, and at the neurological exam identified a condition consistent with post-severe TBI hyperkinetic extrapyramidal syndrome, of the rest tremor type. Treatment with haloperidol $2.5 \mathrm{mg}$ was initiated and controlled the symptoms.

\section{Discussion}

Traumatic brain injury is more frequent in young adults and adolescents. ${ }^{1}$ Its incidence varies according to gender, being higher in men than in women, possibly reflecting differences in the exposure to risk situations. ${ }^{1}$ Regarding the external causes of trauma, accidents with motor vehicles-cars and motorcycles-have been largely responsible for TBI cases. ${ }^{2,3}$ The most commonly injured cranial area in TBI is the frontal region; intracranial hemorrhage is more common than traumatic subarachnoid hemorrhage (TSAH). ${ }^{1,2}$

A definite brain lesion established after a TBI results from physiopathological mechanisms initiated by the accident, which may last for days or weeks. ${ }^{10}$ Acceleration, deacceleration, and rotational forces, as well as piercing objects, can cause laceration, compression, tension, or shearing of tissues, or even a combination of such harmful events, which result in primary brain lesions - concussion, brain contusion, or diffuse axonal lesion of the white matter. ${ }^{10}$ Causes for secondary lesions can arise during the trauma or after some time. ${ }^{11,12}$

The cognitive sequelae observed in TBI patients include somatic, perceptive, cognitive, and emotional symptoms that can be characterized as a postconcussion or as a posttraumatic syndrome. ${ }^{11}$ This condition has been described more frequently in patients who did not require hospitalization or who had brief post-traumatic amnesia, lasting for $<24$ hours, and who did not present with any abnormalities in neuroimaging scans. ${ }^{11}$

Regarding motor sequelae, many patients present a hemiplegic and/or hemiparetic pattern, with gait alterations and functional mobility abnormalities in the superior and/or in the inferior limbs due to lesions in the pyramidal tract. $^{5}$ Lesions involving the pyramidal tract evolve with spasticity and exacerbated tendinous reflexes. ${ }^{13}$

Involuntary movements that can compromise voluntary motricity may be observed if the lesions involve the basal ganglia. ${ }^{13}$ The frequency of involuntary movements as a sequela of TBI is not well known due to the limited number of publications in the medical literature. ${ }^{14-17}$ In the pediatric group, tremor as a sequela of TBI was observed in up to $45 \%$ of the patients, and the symptoms began, in $~ 90 \%$ of the cases, up to 12 months after the trauma. ${ }^{18}$ 


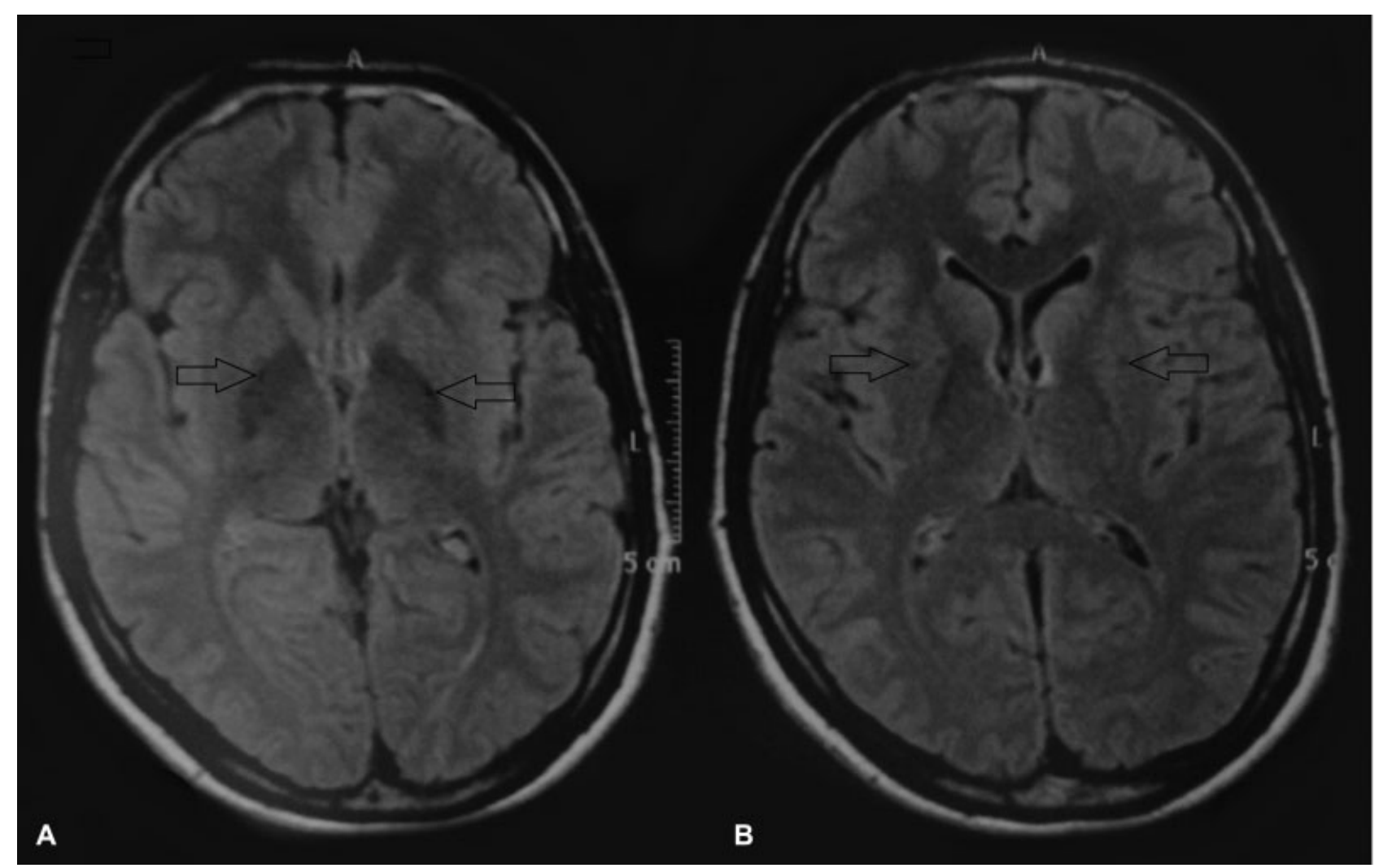

Fig. 1 Cranial axial magnetic resonance imaging - Flair sequence. (A) Note the presence of bilateral hypointense points, indicated by the arrows, in the globus pallidus, corresponding to areas of post-traumatic brain injury gliosis. (B) Note the presence of bilateral hypointense points, indicated by the arrows, in the putamen, also corresponding to areas of post-traumatic brain injury gliosis.

Extrapyramidal syndromes can be classified in two categories: hypokinetic syndromes (akinetic-rigid), and hyperkinetic syndromes. ${ }^{8,13}$ The former are clinically characterized by a reduced velocity in spontaneous movements (bradykinesia) and rigidity. ${ }^{8}$ The latter are characterized by abnormal involuntary movements (tremor, chorea, athetosis, and ballismus). ${ }^{8}$

According to the phenomenological classification by Jankovic, tremors can be divided in rest tremors, action tremors, miscellaneous tremors, and other rhythmic movements. ${ }^{19}$

- Rest tremor is characterized as a limb tremor corresponding to the muscles that were not activated for the movement. ${ }^{20}$

- Action tremor occurs when there is a voluntary muscle contraction. It can be subdivided in postural, kinetic, positional, task-specific, and isometric tremors. ${ }^{19}$

- Postural tremor occurs when moving to the orthostatic position in order to move towards an object. ${ }^{21}$

- Kinetic tremor occurs when movement is initiated, and it is sustained for the duration of the movement. ${ }^{21}$

- Position-specific tremor occurs in certain postures; for instance, with a cup or glass near the mouth, or when in biped position; in the latter case, it is called orthostatic tremor. ${ }^{21}$

- Action-specific tremor occurs in certain activities; for instance, writing (primary writing tremor), speaking or singing (vocal tremor). ${ }^{21}$

- Isometric tremor appears during voluntary muscle contraction sustained against a certain fixed object. ${ }^{21}$
- Essential tremor is the most common pathological tremor and the most frequent movement disorder. ${ }^{21,22}$ It is classically defined by a bilateral, fine postural tremor, visible to the naked eye, persistently affecting the hands, lasting for $>5$ years. $^{21,22}$ Moreover, it can be associated with a kinetic tremor or with a concomitant tremor in other body regions, as in the hands. Sometimes, the amplitude of the tremor fluctuates, often between 4 and $12 \mathrm{~Hz}^{21,22}$

- Fine tremor affects the ability to control small muscles for delicate and specific movements, such as in writing. ${ }^{23}$

- Gross tremor involves wide movements, such as walking and running, through the contraction of large body muscles. ${ }^{23}$

There is also a tremor classification considering its electrophysiological data: low frequency tremors present in frequencies between 2.5 and $4 \mathrm{~Hz}$, and high frequency tremors present in frequencies $>5 \mathrm{~Hz} .{ }^{19}$

It should be emphasized that the pathophysiology of the extrapyramidal syndrome due to TBI is independent from the severity and presence of coma, although the neuroanatomic basis for the post-traumatic tremor remains unknown. ${ }^{20}$ It has been observed that the postural and kinetic tremor of the hand is often asymmetrical and tends to be concomitant to head, leg and trunk tremors, beginning several weeks after the cranial injury. ${ }^{20}$

A study by Johnson et al suggested that midbrain lesions could be associated with the genesis of extrapyramidal 
syndrome, which was analyzed in a sample of 289 children, 199 of whom presented tremors after suffering a TBI. ${ }^{18}$ In neuroimaging tests, the lack of consistent findings in CT and MRI may infers that the lesions responsible for tremor are of biochemical nature. ${ }^{20}$ In the present case, although there were no changes in the initial CT, the MRI of the head revealed alterations consistent with bilateral gliosis areas in the putamen and in the globus pallidus. Iwadate et al, in a case series of Japanese patients who suffered severe TBI, also observed a predominance of midbrain lesions, even though the patients presented late diffuse brain lesions in CT scans. ${ }^{24}$

Regarding the drug therapy for extrapyramidal syndrome resulting from TBI, papers dealing with the subject describe the use of different pharmacological groups. Some cases were successfully treated with benzodiazepines, $\beta$-blockers and anticonvulsants. ${ }^{20} \mathrm{~A}$ study in children with post-TBI tremor showed that propranolol therapy was satisfactory for symptom control. ${ }^{20}$ Drake et al also obtained a satisfactory control with the use of benzodiazepines and anticonvulsants, such as phenobarbital, carbamazepine, and phenytoin. ${ }^{15}$ In the present case report, haloperidol lead to a good control of the symptoms. The drugs used in the conservative treatment of the tremor belong to different pharmacological groups. Some drugs act on different ion channels present in the axons, reducing the triggering of action potentials. Others act by reducing the activity of the sympathetic autonomic nervous system, and some influence the dopaminergic system, interfering directly in the circuits between the basal ganglia and the cerebral cortex. ${ }^{25}$ Another differentiation should also be considered. Haloperidol is an antipsychotic of the butyrophenone group that blocks postsynaptic mesolimbic D1 and D2 dopaminergic receptors. ${ }^{25}$ Propranolol, an antihypertensive and non-selective blocker of $\beta 1$ and $\beta 2$ receptors, can reduce the activity of the autonomic sympathetic nervous system. ${ }^{25}$ It is noteworthy that the mechanism of action of the anticonvulsant phenobarbital is not yet fully known. This drug probably binds to an allosteric regulatory site at the $\gamma$-aminobutyric acid $A$ $\left(G_{A B A}\right)$ receptor, extending the opening time of the chloride ion $\left(\mathrm{Cl}^{-}\right)$channels. ${ }^{25}$ Similarly, phenytoin acts as an anticonvulsant, and its mechanism of action is the reduction of the triggering of action potentials by blocking voltage-activated sodium (Nap) channels. ${ }^{25}$ Finally, the mechanism of action of carbamazepine is based on sodium channels blockade, which also reduces the triggering of action potentials. ${ }^{25}$

Among the surgical options, deep cerebral stimulation of the thalamus is highlighted, more precisely in the ventrooralis posterior/ventral intermedius nuclei (Vop/Vim) complex, with satisfactory control of the symptoms. ${ }^{26}$ MartínezMañas et al achieved a good control in a teenager presenting with a mixed hyperkinetic syndrome manifested by tremor, hemiballism and chorea that were refractory to oral medication. ${ }^{26}$ Andrew et al, in a case series of eight patients with extrapyramidal syndrome due to TBI, also obtained a good control of the symptoms through thalamotomy performed through stereotaxis in the Vim complex..$^{20,27}$ In this series, some of the patients developed, as a postoperative complication, a worsening of the dysarthria and of the hemiparesis already present before the procedure. ${ }^{20,27}$ It is important to emphasize that deep brain stimulation has been a form of non-ablative and reversible treatment when compared with stereotactic lesionectomy. Sitsapesan et al showed the feasibility of post-TBI tremor treatment through deep cerebral stimulation. The work of these authors included eight patients whose brain stimulation involved the posterior Vop and an uncertain zone with a control of the severity of symptoms of $\sim 80 \%{ }^{28}$

Regarding the prognosis of the patients with extrapyramidal syndrome resulting from TBI, it was noted that, in half of the cases of a large series, the symptoms disappeared spontaneously over time. ${ }^{18}$

\section{Conclusions}

Traumatic brain injury sequelae revealed by extrapyramidal syndrome are often rare. Their pathophysiology is not well understood yet, and it is possibly associated with basal ganglia and/or midbrain lesions. In several cases, conservative treatment with different drugs, such as benzodiazepines, anticonvulsants and $\beta$-blockers, was performed. Among the surgical treatments, stereotactic thalamotomy and, more recently, deep brain stimulation, are highlighted. The patient whose case is described in the present study presented a satisfactory control of the tremor with haloperidol. Thus, the optimal therapy for post-TBI extrapyramidal syndrome control is yet to be well defined, thus requiring new studies and broad discussions.

\section{References}

1 Moura JC, Rangel BLR, Creôncio SCE, Pernambuco JRB. Perfil clínico-epidemiológico de traumatismo cranioencefálico do Hospital de Urgências e Traumas no município de Petrolina. Arq Bras Neurocir 2011;30(03):99-104

2 Maia BG, Paula FRP, Cotta GD, et al. Perfil Clínico-Epidemiológico das Ocorrências de Traumatismo cranioencefálico. Rev Neurocienc 2013;21(01):43-527

3 Ruy EL, Rosa MI. Perfil epidemiológico de pacientes com traumatismo crânio encefálico. Arquivos Catarinenses de Medicina 2011; 40(03):17-20

4 Gentili JKA, Himuro HS, Rojas SSO, Veiga VC, Amaya LEC, Carvalho JC. Condutas no paciente com trauma crânio encefálico. Rev Bras Clin Med 2011;9(01):74-82

5 Diretrizes de atenção à reabilitação da pessoa com traumatismo cranioencefálico-Ministério da Saúde. Secretaria de Atenção à Saúde. Departamento de Ações Programáticas Estratégicas. - Brasília: Ministério da Saúde; 2013

6 Spanholi LE. Efeitos neuropsicológicos do traumatismo craniencefálico. Psychiatry on line Brasil 2007;12(08):

7 Barbosa M. Traumatismos Cranioencefálicos. Curso de Pós Graduação em Medicina de Trabalho - Faculdade de Medicina da Universidade de Coimbra. Hospitais da Universidade de Coimbra; 2011:28

8 Júnior COG, Felício AC, Prado GF. Sistema Extrapiramidal: Anatomia e Síndromes Clínicas. Rev Neurocienc 2006;14(01):48-51

9 Scott BL, Jankovic J. Delayed-onset progressive movement disorders after static brain lesions. Neurology 1996;46(01):68-74

10 Andrade AF, Paiva WS, Amorim RL, Figueiredo EG, Rusafa Neto E, Teixeira MJ. The pathophysiological mechanisms following traumatic brain injury. Rev Assoc Med Bras (1992) 2009;55(01):75-81 
11 Fraga-Maia H. "Vida após o trauma": do evento à funcionalidade dos sobreviventes de traumatismo cranioencefálico. Programa de Pós-Graduação em Saúde Coletiva- Universidade Federal da Bahia. Salvador, 2010

12 Oliveira E, Lavrador JP, Santos MM, Lobo Antunes J. [Traumatic brain injury: integrated approach]. Acta Med Port 2012;25(03): 179-192

13 Lee MS, Marsden CD. Movement disorders following lesions of the thalamus or subthalamic region. Mov Disord 1994;9(05):493-507

14 McArthur DL, Chute DJ, Villablanca JP. Moderate and severe traumatic brain injury: epidemiologic, imaging and neuropathologic perspectives. Brain Pathol 2004;14(02):185-194

15 Drake ME Jr, Jackson RD, Miller CA. Paroxysmal choreoathetosis after head injury. J Neurol Neurosurg Psychiatry 1986;49(07): 837-838

16 Spitz M. Doença de Huntington e Outras Coreias. Revista Hospital Universitário Pedro Ernesto da Universidade Estadual do Rio de Janeiro 2010; 9(1)

17 Krauss JK. Movement disorders secondary to craniocerebral trauma. Handb Clin Neurol 2015;128:475-496

18 Johnson SLJ, Hall DMB. Post-traumatic tremor in head injured children. Arch Dis Child 1992;67(02):227-228

19 de Mattos JP. [Differential diagnosis of tremors]. Arq Neuropsiquiatr 1998;56(02):320-323
20 Biary N, Cleeves L, Findley L, Koller W. Post-traumatic tremor. Neurology 1989;39(01):103-106

21 Krauss JK, Tränkle R, Kopp KH. Post-traumatic movement disorders in survivors of severe head injury. Neurology 1996;47(06):1488-1492

22 Leite MA. Tremor Essencial. Revista Hospital Universitário Pedro Ernesto da Universidade Estadual do Rio de Janeiro 2010; 9(1)

23 Hounsell MS, Xavier DC, Crocetta TB, Andrade A. Análise do Controle Motor com Interações baseadas em Dispositivos Convencionais e Realidade Aumentada. Revista de Informática Teórica e Aplicada. 2010;17(02):154-173

24 Iwadate Y, Saeki N, Namba H, Odaki M, Oka N. [Intention tremor after head injury. Clinical features and computed tomographic findings]. Neurol Med Chir (Tokyo) 1989;29(02):122-127

25 Rang HP, Dale MM, Ritter JM, Flower RJ, Henderson G. Farmacologia. 7th ed. Rio de Janeiro: Elsevier; 2012

26 Martínez-Mañas R, Rumià J, Valldeoriola F, Ferrer E, Tolosa E. Neuroinhibición tal mica para el tratamiento del temblor postraumático. Rev Neurol 2002;34(03):258-261

27 Andrew J, Fowler CJ, Harrison MJ. Tremor after head injury and its treatment by stereotaxic surgery. J Neurol Neurosurg Psychiatry 1982;45(09):815-819

28 Sitsapesan HA, Holland P, Oliphant Z, et al. Deep brain stimulation for tremor resulting from acquired brain injury. J Neurol Neurosurg Psychiatry 2014;85(07):811-815 